\title{
PROJECT BASED LEARNING FOR INFORMATION SYSTEMS STUDENTS. AN IMPLEMENTATION PROPOSAL
}

\author{
Andrés Boza1, Leonor Ruiz-Font ${ }^{1}$, Laura Mota-Herranz ${ }^{2}$ \\ ${ }^{1}$ Dpto. Organización de Empresas, Escuela Técnica Superior de Ingeniería Informática. \\ Universitat Politècnica de València (SPAIN) \\ ${ }^{2}$ Dpto. Sistemas Informáticos y Computación, Escuela Técnica Superior de Ingeniería \\ Informática. Universitat Politècnica de València (SPAIN)
}

\begin{abstract}
This paper presents a proposal for the implementation of the project-based learning technique for students of Computer Engineering in the Information Systems specialization. The project involves three subjects of that specialization. The design of the proposal has required coordination between the participating subjects, among other things such as the coordination of the calendar that each subject addresses, the establishment of joint teams of students or the design of deliverables. As a result, the coordinated project gives prominence to the students and focuses on the work process with an interdisciplinary perspective between subjects. An important change Is a new evaluation method in agreement with the combination of competences from the different subjects and their integration.
\end{abstract}

Keywords: Project based learning, PBL, Information Systems.

\section{INTRODUCTION}

Project-Based Learning (PBL) techniques offer a collection of tools and criteria with great potential for the renewal of the teaching-learning process [1]. Problem-based and project-based learning is a recognized worldwide education practice that can produce soft skills, professional skills and knowledge for students. To do this, it uses teamwork, unstructured problems, exemplary and real projects, teacher support and social engagement encouraging cooperation and collaboration [2]. The main characteristics of PBL are: 1) the tutor's role as a facilitator of learning, 2) learners' responsibilities to be self-directed and self-regulated in their learning, and 3) the essential elements in the design of ill-structured instructional problems such as the driving force for enquiry. The challenge for many instructors when they adopt a PBL approach is to make the transition from the teacher as a knowledge provider to the tutor as a manager and facilitator of learning [3]. In a PBL approach, the tutor supports the process and expects learners to make their thinking clear, but the tutor does not provide information related to the problem because that is the learners' responsibility. Problem-based learning can offer students opportunities to learn how to learn, and to develop key skills, independence in enquiry, and the ability to contrast ideas and debate [4].

A new structure in the teaching-learning process needs to be included. Thus, lecturers have to make an effort to include this technique. This change is even greater in the case of PBL proposals where several subjects participate in the project so that there must exist coordination among them in the planning and organization, monitoring, and evaluation.

The change of management required to transform traditional teaching-learning systems to $\mathrm{PBL}$ proposals is complex. It is a long, comprehensive and energy consuming process [5].

The Technical School of Computer Engineering in the Universitat Politècnica de València does not reject possible changes of improvement, and in that sense, it has defined an Educational Innovation and Improvement Project with the title "Project Based Learning in Engineering Computing Degrees ". The Faculty of the Information Systems branch is becoming part of this initiative by designing a joint project. The subjects of this branch that are participating in the joint project are Business Models (MNE), Design and Management of Databases (DBD), and Integrated Information Systems in Organizations (SIO). All of them are included in the fourth course.

The relevance of this proposal lies in the combination of the particular vision of the subjects participating in the PBL along with a global vision of the project. Thus, our proposal combines global planning and organization, as well as monitoring, and evaluation with a particular one of each subject. 


\section{PROJECT PROPOSAL}

The general objective of the joint project is that students are able to obtain knowledge and skills in techniques and methods for solving problems in the field of information systems, as demanded by organizations.

The scope regarding the outcome of the project will be that each student team develops a different project, proposed by the team itself, but guided by lecturers.

The proposed project for students is:

The creation of a company, analyzing its business processes, the needs of its information system, identifying existing business IT solutions in the market that allow them to cover these needs, and designing a database that allows the storing of information of a particular aspect of that company.

Thus, the student uses the context of the project as a case study for the application and acquisition of knowledge of the subjects, and develops a realistic product as a result of the project.

The proposed project requires skills and abilities as discussed in the three participating subjects to achieve the objectives.

\section{LEARNING OUTCOMES}

The following learning outcomes are expected to be obtained by students with the project development:

\begin{tabular}{|l|l|}
\hline \multicolumn{2}{|l|}{ SUBJECT 1: Business Models (MNE) } \\
\hline COMPETENCE & LEARNING OUTCOMES \\
\hline $\begin{array}{l}\text { Ability to understand and apply the } \\
\text { principles and practices of organizations, } \\
\text { so that they can act as a liaison between } \\
\text { the technical and management } \\
\text { communities of an organization and } \\
\text { actively participate in the training of users. }\end{array}$ & $\begin{array}{l}\text { Students will be able to properly select and use tools for the } \\
\text { creation of business models, analyse the key issues that determine } \\
\text { the viability of a company, and the formal generation of a business } \\
\text { plan and its feasibility analysis. }\end{array}$ \\
\hline Innovation, Creativity and entrepreneurship & $\begin{array}{l}\text { Students will be able to look for opportunities, through the } \\
\text { generation of ideas, to finally carry out their implementation } \\
\text { through an action plan and their value analysis. }\end{array}$ \\
\hline
\end{tabular}

\begin{tabular}{|l|l|}
\hline \multicolumn{2}{|l|}{ SUBJECT 2: Design and Management of Databases (DBD) } \\
\hline COMPETENCE & LEARNING OUTCOMES \\
\hline $\begin{array}{l}\text { Ability to integrate Information Technology } \\
\text { and Communications and business } \\
\text { process solutions to meet the information } \\
\text { needs of organizations, allowing them to } \\
\begin{array}{l}\text { achieve their objectives effectively and } \\
\text { efficiently, thus giving them competitive } \\
\text { advantages. }\end{array}\end{array}$ & $\begin{array}{l}\text { Students will be able to determine which solutions are best suited } \\
\text { for the design of a specific information system. Students must } \\
\text { make a study of the efficiency. }\end{array}$ \\
\hline $\begin{array}{l}\text { Ability to actively participate in the } \\
\text { specification, design, implementation and } \\
\text { maintenance of information and } \\
\text { communication systems }\end{array}$ & $\begin{array}{l}\text { Students will be able to design an information system with a } \\
\text { database as the centre of the system. The knowledge presented } \\
\text { in the theory classes should guide the design to ensure that the } \\
\text { system behaves efficiently, satisfying all the requirements } \\
\text { detected in the analysis. }\end{array}$ \\
\hline
\end{tabular}




\begin{tabular}{|l|l|}
\hline SUBJECT 3: Integrated Information Systems in Organizations (SIO) \\
\hline COMPETENCE & LEARNING OUTCOMES \\
\hline $\begin{array}{l}\text { Ability to integrate Information Technology } \\
\text { and Communications and business } \\
\text { process solutions to meet the information } \\
\text { needs of organizations, allowing them to } \\
\begin{array}{l}\text { achieve their objectives effectively and } \\
\text { efficiently, thus giving them competitive } \\
\text { advantages. }\end{array}\end{array}$ & $\begin{array}{l}\text { Students will be able to identify ICT business solutions and } \\
\text { business processes to meet the information needs of } \\
\text { organizations, allowing them to achieve their objectives effectively } \\
\text { and efficiently, thus giving them competitive advantages. This } \\
\text { identification and analysis of the situation in the company will } \\
\text { enable the student to integrate these systems into the } \\
\text { organization. }\end{array}$ \\
\hline Innovation, Creativity and entrepreneurship & $\begin{array}{l}\text { Students will be able to look for opportunities, through the } \\
\text { generation of ideas, to finally carry out their implementation } \\
\text { through an action plan and their value analysis. }\end{array}$ \\
\hline
\end{tabular}

\section{ORGANIZATION OF THE PROPOSAL}

The design of the proposal has required coordination between the participating subjects, among other things, i) the calendar that each subject addresses, ii) the establishment of joint teams of students or iii) the design of deliverables.

The number of students for each group was set at 3 students. The formation of each group will be free for the students and no predetermined roles will be established in each group. Thus, the responsibility of the internal organization of each group (temporary planning, distribution of tasks, etc.) is left to the students.

The Project has been structured, firstly, working on a Global Vision, secondly working in the field of each subject, to finally to be able to integrate the work as a joint project (Fig. 1).

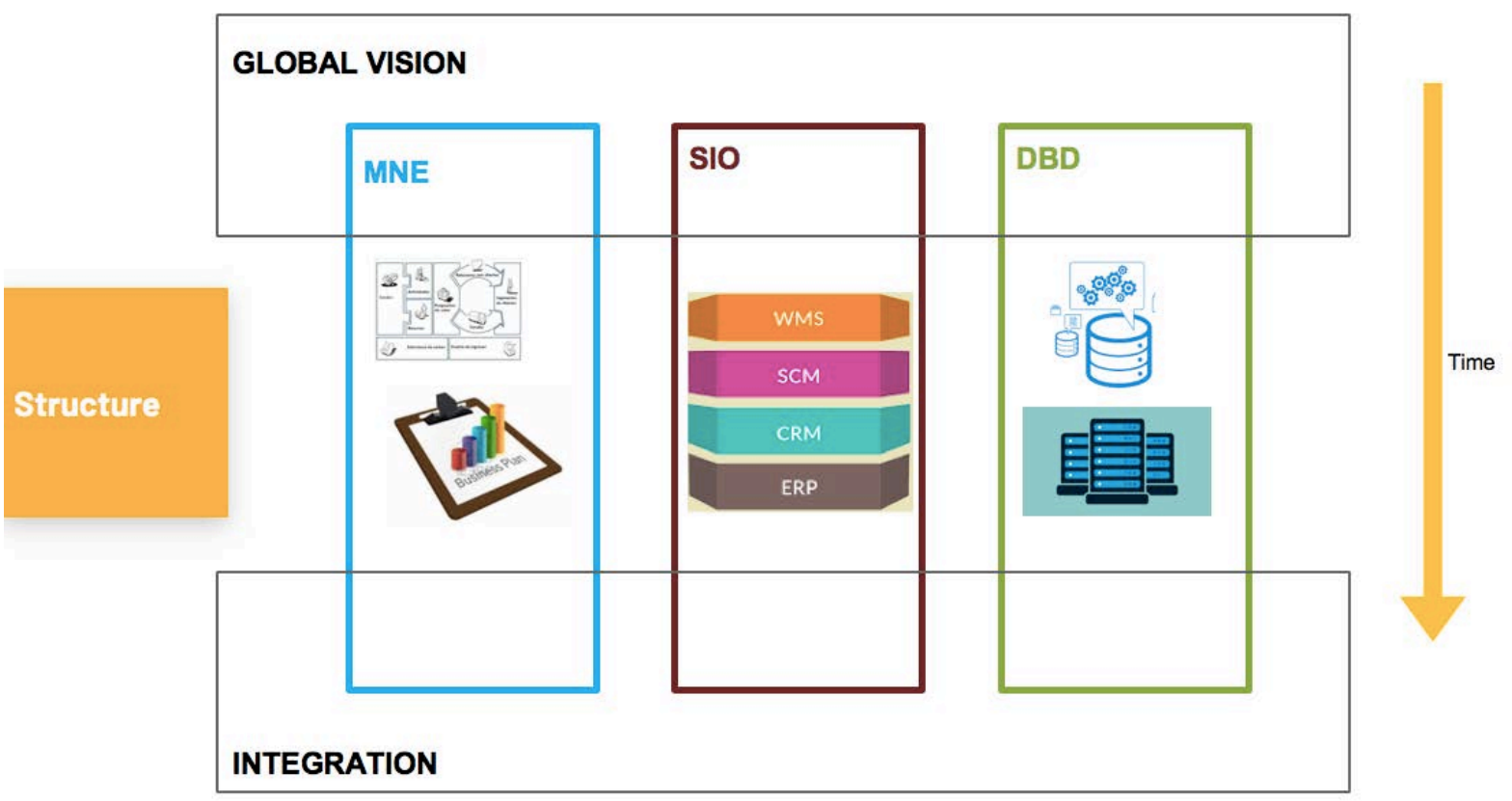

Figure 1. Structure of the joint project

Each subject requests deliverables during the development of the joint project, and in the final stage a final report of the project and its oral presentation are requested (Fig. 2).

- Final Report: The report must include the analysis of the situation and the design of the proposals made by each group. It must have a global perspective and will incorporate and integrate in a single document the aspects dealt with in the three subjects.

- Oral presentation: Students must make a presentation of the project where all the members of the group will participate. 


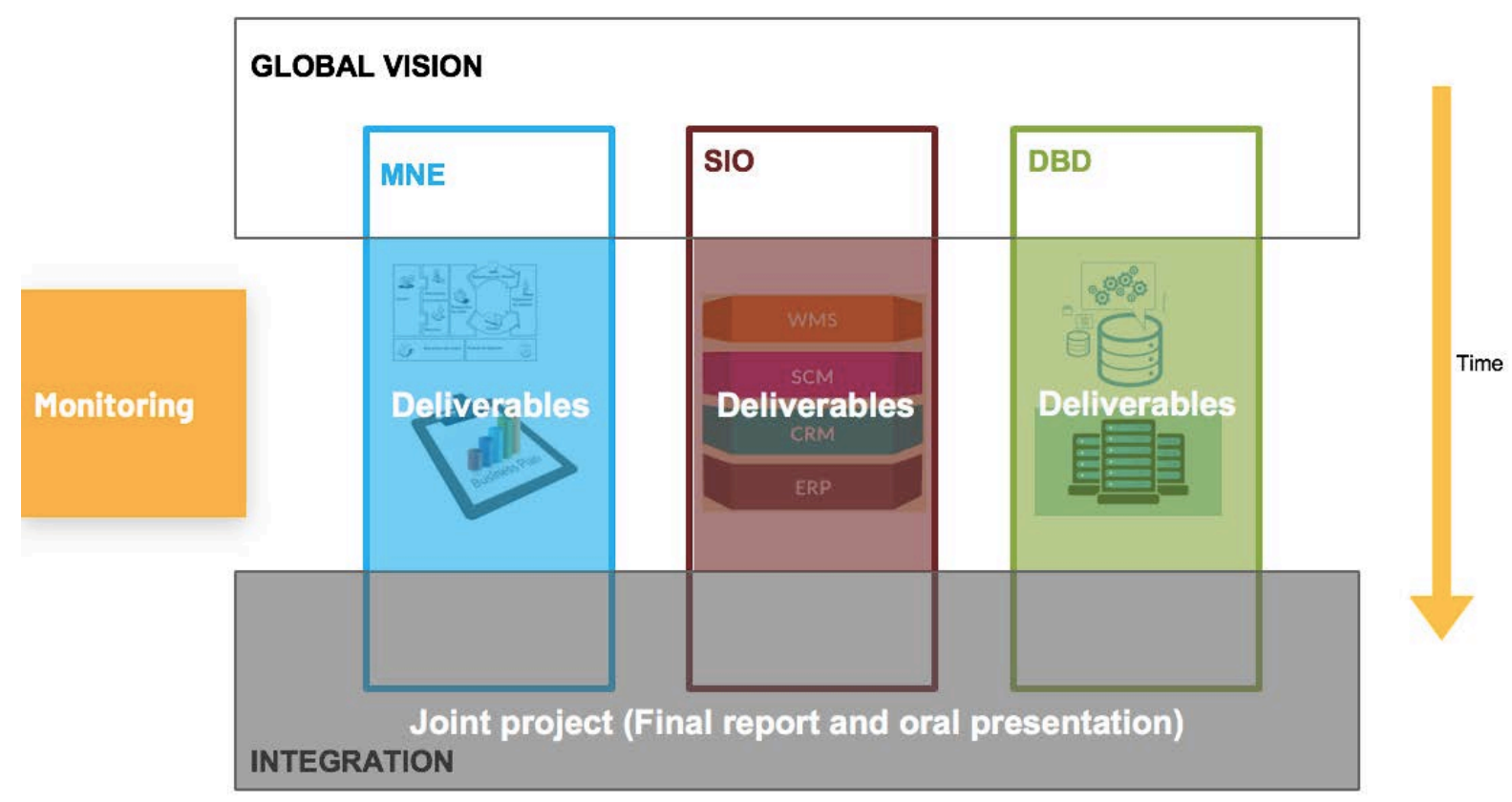

Figure 2. Monitoring the joint project

Each subject has to evaluate the students from the perspective of its competences. Students are assessed for each subject in Spain in a range of 0 to 10. To have an adequate balance between the subjects, the same weight for the evaluation has been established in each subject for the project, specifically 3 points in the evaluation.

\section{CONCLUSIONS}

Considering all the facts from above we can say that:

1 The coordinated project gives prominence to the students and focuses on the work process with an interdisciplinary perspective among subjects.

2 This approach will require self-management mechanisms for students.

3 The completion of the project requires a coordination effort between the participating subjects.

4 It is expected that this approach will facilitate the work in transversal competences in a more explicit way.

5 The importance in the change of the evaluation method (combination of competences collected from the different subjects and their integration by the students).

\section{ACKNOWLEDGEMENTS}

This work has been carried out within the framework of the Educational Innovation and Improvement Project ref. ETSINF-1 " Aprendizaje Basado en Proyectos en Ingeniería Informática " of the Universitat Politècnica de València.

\section{REFERENCES}

[1] Domingo, Joan. Técnicas de trabajo en Aprendizaje basado en problemas/proyecto PBL. Taller de formación UPV Enero-Febrero 2015

[2] Rodriguez-Mesa, F., Kolmos, A., Guerra, A. (red.). Aprendizaje basado en problemas en ingeniería: Teoría y práctica. Aalborg: Aalborg Universitetsforlag. 2017

[3] Ertmer, P. A., \& Simons, K. D. Jumping the PBL implementation hurdle: Supporting the efforts of K-12 teachers. Interdisciplinary Journal of Problem-based Learning, 1 (1), 40-54. 2006 
[4] Savin-Baden M. Problem-based Learning in Higher Education: Untold Stories. The Society for Research into Higher Education\& Open University Press. 2000

[5] Kolmos, A. \& Graaff, E. D. Process of Changing to PBL. 2006 In Rodriguez-Mesa, F., Kolmos, A., Guerra, A. (red.). Aprendizaje basado en problemas en ingeniería: Teoría y práctica. Aalborg: Aalborg Universitetsforlag. 2017 